\title{
Notes on Acacia species in Southern Africa: IV
}

\author{
J. H. ROSS*
}

\section{ABSTRACT}

Information concerning miscellaneous $A$ cacia species is presented, and a new species, $A$. redacta J. H. Ross, from the northern Cape Province is described.

\section{ACACIA CALLICOMA MEISN}

Meisner, in Hook., Lond. J. Bot. 2: 104 (1843), based his description of $A$. callicoma on a specimen without fruits, and doubtfully from Natal, seen in Krauss' herbarium. No type specimen was cited and I have not succeeded in tracing a specimen bearing this name or any further reference to the species in literature. Neither Harvey in Fl. Cap., vol. 2 (1862), nor Bentham in his revision of Mimoseae in Trans. Linn. Soc. Lond. vol. 30 (1875), mention A. callicoma. The description suggests that the specimen Meisner saw was not an Acacia but, in the absence of a specimen, the precise identity of $A$. callicoma remains unresolved.

\section{ACACIA REDACTA $J$. H. ROSS}

Acacia redacta $J$. H. Ross, sp. nov., ab omnibus speciebus africanis distincta, affinitate incerta.

Frutex ramosissimus, $0,3-0,6 \mathrm{~m}$ altus; ramuli fusco-griseo-brunnei. Ramuli juveniles rubrobrunnei, dense et persistenter appresse pubescentes, glandulis numerosi minimi atropurpureis conspicuis inter pilos immixtis. Spinae stipulares geminae, plus minusve elongatae, 0,8-1,4 cm longae, rubrobrunneae, rectae sed saepe deflexae. Folia: petiolus brevis, plerumque 2-6 mm longus, griseo-puberulus, apice eglandulosus; pinnae 1-jugatae; rhachillae $0,4-1,8 \mathrm{~cm}$ longae, subglabrae vel puberulae; foliola 2-4-juga, 2-5, $5 \mathrm{~mm}$ longa, 1,2-3,5 mm lata, oblique oblonga vel elliptica vel \pm subrotundata, apice rotundata vel obtusa, pagina appresse pubescenti, costa et nervis lateralibus subtus haud perspicuis vel obscuris. Inflorescentiae ut videtur capitatae, redactae; flores $2-4$ pro inflorescentiam vel solitarii; pedunculi axillares, $2-6 \mathrm{~mm}$ longi, ut ramuli conspicue glandulosi, dense appresse pubescentes. Flores ut videtur flavidi. Calyx cupularis, 0,8-1,2 mm longus, quinquedenticulatus, dense pubescens. Corolla 4-6 mm longa, praesertim in lobis dense appresse pubescens vel tomentella. Stamina numerosa, filamentis $14-17 \mathrm{~mm}$ longis, basi breviter connatis et breviter tubulosis. Ovarium breviter stipitatum, $\pm 1,5 \mathrm{~mm}$ longum. Stylus $\pm 17-19 \mathrm{~mm}$ longus. Legumina $2,6-3,2 \mathrm{~cm}$ longa, 0,9-1, $1 \mathrm{~cm}$ lata, linearioblonga, recta, 1-2-sperma, subroseo-brunnea, dense appresse griseo-puberula, glandulis numerosis minimi atropurpureis sessilibus conspicuis inter pilos immixtis, apice acuta vel acuminata, dehiscentia. Semina non visa.

TyPE: Cape, 2817 (Vioolsdrif): 22,4 km north of Stinkfontein on way to Jenkinskop (-CB), on steep west-facing ridge of schistoid granite, on border of Namaqualand Broken Veld and Western Mountain Karoo, M. J. A. Werger 1518 (PRE, holo.; K, iso.).

Much-branched shrub 0,3-0,6 m high; branches dark grey-brown, flaking minutely. Young branchlets reddish-brown, densely and persistently appressed pubescent, with numerous small, conspicuous, dark purplish glands among the hairs. Stipules spinescent, in pairs, $0,8-1,4 \mathrm{~cm}$ long, reddish-brown, straight or often deflexed, slender. Leaves: petiole short,

* Botanical Research Institute, Department of Agricultural Technical Services, Private Bag X101, Pretoria. mostly 2-6 mm long, grey-puberulous, eglandular apically; pinnae 1 pair; rhachillae $0,4-1,8 \mathrm{~cm}$ long, subglabrous or puberulous; leaflets $2-4$ pairs, $2-5,5$ $\mathrm{mm}$ long, 1,2-3,5 $\mathrm{mm}$ wide, oblique, oblong or elliptic or \pm subrotund, apex rounded or obtuse, surfaces appressed pubescent, midrib and lateral nerves not visible or inconspicuous beneath, with minute reddish glands at the point of attachment of the leaflets. Inflorescences apparently capitate, reduced; flowers 2-4 per inflorescence or sometimes solitary; peduncles axillary, 2-6 $\mathrm{mm}$ long, conspicuously glandular like the branchlets, densely appressed pubescent. Flowers apparently pinkish. Calyx cupular, 0,8-1,2 mm long, 5-toothed, densely pubescent. Corolla $4-6 \mathrm{~mm}$ long, lobes densely appressed pubescent or tomentellous. Stamens numerous, filaments 14-17 mm long, shortly connate basally and shortly tubular. Ovary shortly stipitate, $\pm 1,5 \mathrm{~mm}$ long. Style $+17-19 \mathrm{~mm}$ long. Pods $2,6-3,2 \mathrm{~cm}$ long, $0,9-1,1 \mathrm{~cm}$ wide, linear-oblong, straight, 1-2 seeded, pinkish-brown, densely appressed grey-puberulous, numerous small, conspicuous, dark purplish sessile glands among the hairs, apex acute or acuminate, dehiscent. Seeds not seen.

The first specimens of this plant were collected by Dr O. A. Leistner and Dr M. J. A. Werger in the north-western Cape Province in 1969. In response to a request for more material, the latter, who is undertaking a survey of the Orange River, collected a further set of specimens in December 1971.

While the capitate heads or elongate spikes in all other African species of Acacia contain numerous flowers, in this plant the inflorescences are greatly reduced and the "heads" contain only $2-4$ flowers or, rarely, the flowers appear to be solitary. This reduction in the number of flowers per "head" is coupled with an increase in the size of the individual flowers, the flowers being larger than in most other species of African Acacia. The stamen-filaments are united basally for $\pm 2 \mathrm{~mm}$ into a tube, which is a character shared by only a few other species, for example, $A$. albida Del. and $A$. eriocarpa Brenan. Unfortunately no young anthers are available for examination so it has not been possible to establish whether or not the anthers have an apical caducous gland. More flowering material is required and flower colour needs confirmation. The pods, which are very small, dehisce longitudinally from the apex downwards and the two valves diverge. Unfortunately no seeds are available to establish whether or not they have the characteristic areole. However, even if absent, they would not be without parallel for the seeds of $A$. leucospira Brenan lack an areole.

Although it differs from all the other African species of Acacia in lacking many-flowered capitula or spikes, it would seem unwise to separate this plant generically from Acacia. The presence of \pm straight, paired, stipular spines, small bipinnate leaves, flowers with numerous stamens, \pm straight, dehiscent pods, and the overall facies, suggest that the plant is an Acacia. The plants are of very small stature but this 



FIG, 1.-Specimen of Acacia redacta growing on a steep, west-facing ridge of schistoid granite, $22,4 \mathrm{~km}$ north of Stinkfontein on the way to Jenkinskop, northern Cape Province, A dehisced pod with diverging valves is visible towards the right-hand side of the plant.

FIG. 2.-The habitat occupied by Acacia redacta on the border of Namaqualand Broken Veld. Many Aizoaceous genera are present and species of Crassula, Cotyledon and Euphorbia are common. 
is thought to be the result of the extreme and inhospitable environment they occupy, an environment which is conducive to shrubbiness and in which the arborescent growth form is not well represented. (See Figs. 1 \& 2). The reduction in the number of flowers per inflorescence is also a possible result of the adverse environment.

A. redacta appears to have a very restricted distribution in the north-western Cape Province. Apparently it favours rocky ridges.

CAPE.--2817 (Vioolsdrif): 20,8 km north of Stinkfontein (-CB), Leistner $3401 ; 22,4 \mathrm{~km}$ north of Stinkfontein on way to Rosyntjieberg $(-\mathrm{CB})$, Werger $428 ; 22,4 \mathrm{~km}$ north of Stinkfontein on way to Jenkinskop (-CB), Werger 1518.

I am most grateful to Mr J. P. M. Brenan, Keeper of the Herbarium, Royal Botanic Gardens, Kew, for commenting on the above specimens, to $\mathrm{Mr} \mathrm{H} . \mathrm{K}$. Airy Shaw for checking the Latin description, and to Dr Werger for supplying the photographs which accompany this note and for the ecological information.

\section{ACACIA REFICIENS WAWRA-ACACIA LUEDERTIZII ENGL.}

The A. reficiens Wawra-A. lu deritzii Engl. complex was dealt with some years ago (Ross \& Brenan in Kew Bull. 21: 71, 1967). Although A. reficiens and $A$. luederitzii are unquestionably closely related, the two were maintained as distinct species. However, Schreiber in Fl. S.W. Afr. 58: 11 (1967) regarded $A$. reficiens and $A$. luederitzii as conspecific, placing the latter species as a synonym of $A$. reficiens.
Because of these conflicting views, the complex has been re-investigated. The conclusions reached are expressed below.

A. reficiens, which was based on Wawra 248 from between Benguela and Catumbela in Angola, differs from $A$. luederitzii mainly in its indumentum being puberulous or pulverulent without spreading hairs; by the consistently few pairs of leaflets, usually up to 11 , occasionally 13 , pairs per pinna with their margins glabrous or almost so, lacking the spreading cilia; fewer pinnac pairs, $1-4$; and by the tendency for narrower pods. A. reficiens appears to be a fairly uniform species and the two subspecies within it, although separated by a large geographical discontinuity (see Fig. 3), differ very slightly from each other. A. luederitzii appears to be far more variable.

When working on this complex previously, we had on loan the material from the National Herbarium, Pretoria. It was found that the PRE specimen of Murloth 1270, one of the syntypes of A. luederitzii, was in fact a specimen of $A$. reficiens subsp. reficiens, while the specimen of Marloth 1328, the other syntype, matched the illustration and the description of A. luederitzii in Bot. Jahrb. 10: 23, t. 3 B (1888). Consequently, the PRE specimen of Marloth 1328 was selected as the lectotype of A. luederitzii. Since then specimens of Marloth 1328 from the Albany Museum in Grahamstown, the Staatssammlung in München, and the Fielding Herbarium in Oxford have been examined, and all three agree with the PRE specimen. However, the specimen of Marloth 1328 from the Bolus Herbarium, University of Cape Town, is unquestionably a specimen of $A$. reficiens

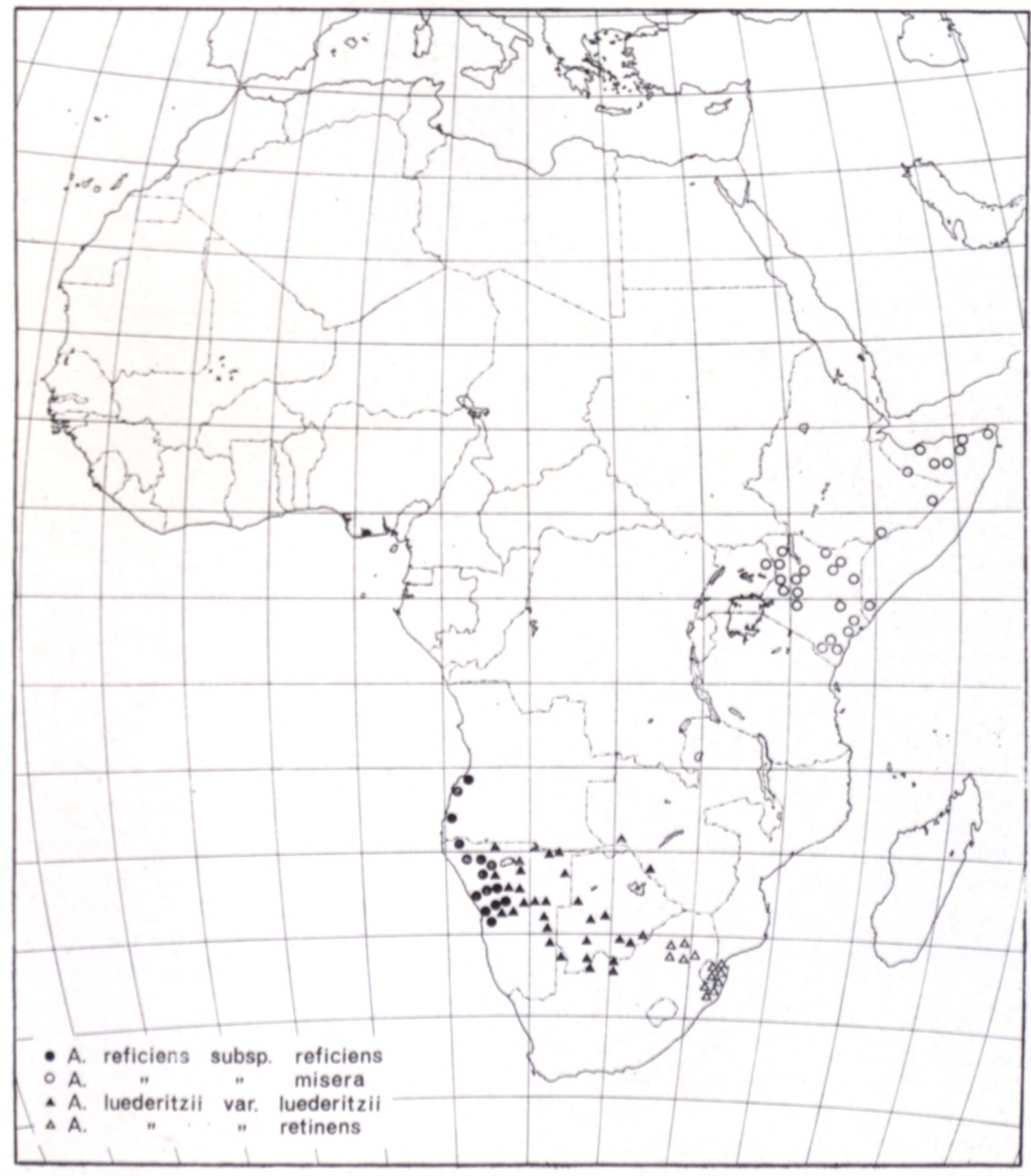

FIG. 3.-The known distributions of Acacia reficiens and $\mathbf{A}$. luederitzii. 